\title{
THE EFFECT OF OPEN ENDED APPROACH ON PROBLEM SOLVING ABILITY AND LEARNING INDEPENDENCE IN STUDENTS' MATHEMATICS LESSONS
}

\author{
Nur Alfiani \\ Hafidzah $^{1+}$ \\ Zainal Azis ${ }^{2}$ \\ Irvan $^{3}$
}

\author{
Master Program of Mathematics Education,Universitas Muhammadiyah of Sumatera Utara \\ ${ }^{2,3}$ Universitas Muhammadiyah of Sumatera Utara \\ 'Email: alfianihafidzah29@gmail.com \\ ${ }^{2}$ Email: zainalazis@umsu.ac.id \\ ${ }^{3}$ Email:irvan@umsu.ac.id
}

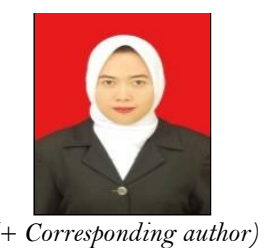

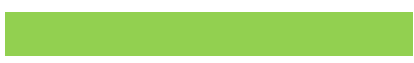

Article History

Received: 4

Revised:

Accepted:

Published:

\section{Keywords}

open ended approach, problem

solving ability, learning

independence

\begin{abstract}
The purpose of this study is to investigate whether 1) solving mathematical problems between students who take learning with an open-ended learning approach and students who take learning without an open-ended learning approach; 2) the influence of mathematical ability among students who have learning independence high, medium and low; 3) whether the Open-Ended learning approaches and student learning independence there was an interaction of the students' mathematical problem solving ability. This research was Quasi Experimental design The Nonequivalent Post-test Only Control Group Design. This study population throughout the first semester of seventh grade students of MTs Negeri 1 Bandar Rice academic year 2018/2019. A research technique used is purposive sampling with a sample class as a class VII-1 and VII-2 experiment as a control group. The research instrument used was a test description to measure students 'mathematical problem solving and a questionnaire to measure students' learning independence. Analysis of the data in this study is a two-way ANOVA. The results of data analysis 1) there is a mathematical problem solving among students who take the learning with the OpenEnded learning approach with students who take the lesson without learning approach OpenEnded; 2) there is an influence on the ability of mathematical problems between students who have high, medium and low learning independence; 3) there is no interaction between the OpenEnded learning approach and students 'learning independence on students' mathematical problem solving ability.
\end{abstract}

\section{INTRODUCTION}

Education is one way of shaping the human ability to use reason and logic optimally as an answer to dealing with problems that arise in an effort to create a good future. Every level of education ranging from basic education to university level mathematics courses given, therefore mathematics plays an important role in improving human resources. Learning mathematics at school focuses on developing students' abilities to solve problems and ultimately can be achieved competencies that can be used to compete in the global era. Ministerial Regulation No. 22 of 2006 regarding content standards in detail explains that mathematics lessons in secondary schools aim to solve problems, this is also in line with the learning abilities formulated by NCTM (Permendikbud, 2016), namely the ability to solve math problems, mathematics communication skills, reasoning abilities mathematics, the ability to represent mathematics and the ability to connect mathematics, from the competencies as presented above, one of the mathematical abilities of students that is very important to be developed among students is problem solving skills.

In the initial research conducted at MTS Negeri 1 Bandar sawah it was found that students' problem solving abilities were still lacking. This can be seen from the students 'answers shown in table 1 when given a set of questions that require problem solving skills. Example when the researcher gave the initial test in the form of questions taken from the 2009 National Examination manuscript to measure the students' mathematical problem solving abilities, the first question given was: "From a group of children in the class, there are 20 children who like English, 30 children who like Indonesian, and 15 children who like English and Indonesian. So many children in that group are ... " and the second question given was taken from the Examination script. National year 2014 reads "There were 40 participants who took part in the competition. 23 people participated in the poetry reading competition, 12 people participated in the poetry reading and short story writing competition. The number of participants who take part in the short story writing competition is ..." 

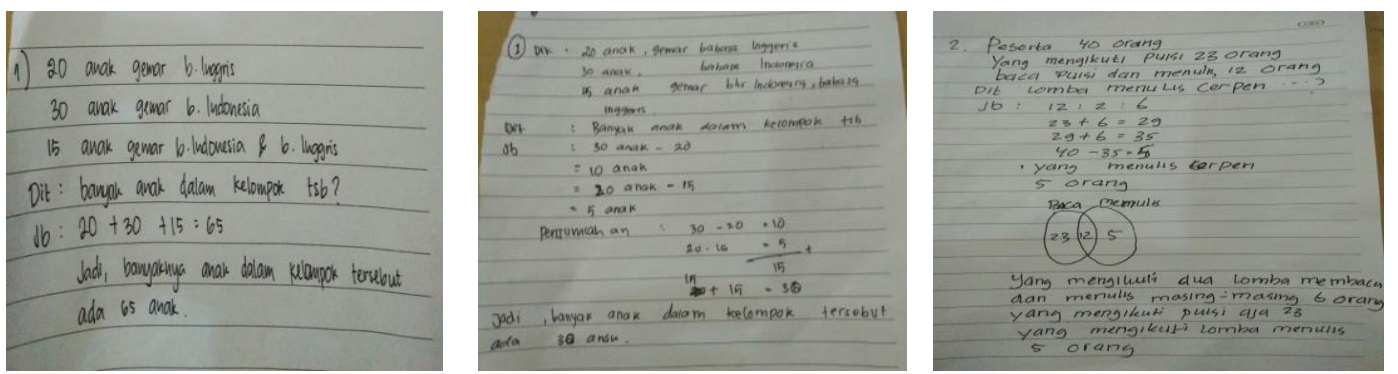

Figure 1: Results of Students' Answers on Mathematical Problem Solving Ability

Based on the results of the initial research in Figure 1 the students were not able to understand the problem or understand or analyze the questions correctly, out of 34 students only 4 were able to answer correctly and understand the questions. Problem-solving skills in the seventh grade students of MTS Negeri 1 Bandar Sawah is very low.

Another aspect that is no less important to pay attention to is the independence of student learning. The independent learning process provides students with learning opportunities to digest teaching material with a little learning assistance. In the process of teaching and learning in the classroom, students also have not been actively involved in, the teacher plays an active role while the students only receive knowledge presented by the teacher. The main source of knowledge in the classroom is still focused on the teacher, where the learning approach used is the lecture method which makes student responses to mathematics less, so that it will result in low math problem solving abilities and student learning independence. According to Martinis Yamin (2008) Independent learning is an effort to develop freedom for students in obtaining information and knowledge that is not controlled by others.

Student independence in learning is one important factor that must be considered in order to achieve good learning outcomes. The demands for the development of independent learning written in the mathematics curriculum include, among other things, that mathematics lessons must instill an attitude of respect for mathematics in life, namely having curiosity, attention, interest in studying mathematics, independent, resilient, and confident in problem solving.

Independence is in the form of gradually from myself, parents, and teachers, but there are still many students that I found in MTS Negeri 1 Bandar Sawah class VII in the 2018/2019 academic year, there are still many students who have not been able to become independent learners. When making preliminary observations, it was found that students did not make preparations before facing learning at school; students only received lessons from the teacher. When working on a question, students have difficulty when given questions that do not match the example questions given previously. Many students do not take the initiative to answer the questions given by the teacher if the teacher has not directed one of the students to answer the questions given. The result is that students tend to see and copy answers from friends when working on assignments, students choose to copy answers from friends rather than looking for their own solutions. Based on this fact, it appears that the learning independence of MTS Negeri 1 Bandar Sawah students is still low.

In the independent learning system, students are expected to learn more independently or in groups with the minimum possible help from others, because it requires ability, strong will and high discipline in carrying out learning activities. A strong will encourage not giving up in facing difficulties, while high discipline is needed so that learning activities are according to their own schedule.

In the process of teaching and learning in the classroom, students also have not been actively involved in, the teacher plays an active role while the students only receive knowledge presented by the teacher. The main source of knowledge in the classroom is still focused on the teacher, where the learning approach used is the lecture method which makes student responses to mathematics less, so that it will result in low math problem solving abilities and student learning independence. In most cases, the success of learning is determined by the teacher's ability to carry out effective learning. Teachers should choose the model of learning, strategy / approach to teaching and learning methods that would allow them to motivate students to be able to understand the concepts and know the procedures to solve problems and create conditions that encourage students to class to find their own new knowledge. According Ruseffendi in satriawati, "the approach is way, way or policies adopted by teachers and students in achieving the goals of teaching views of how the process of teaching or the teaching materials, general or special". because it is necessary to change the learning model that is more meaningful. So the need for changes in teaching methods that are more meaningful. 
The teacher can also apply an approach that emphasizes giving problems, so that learning is not limited to explaining or telling students about mathematical formulas that will be used to solve mathematical problems. The open-ended approach is one problem-based approach. The application of this approach, it is hoped students were able to solve the problem in various ways according to ability. Presentation of the problem motivates students to think creatively and critically in solving various problems with alternative correct answers.

Based on the above problems, learning math should be addressed to enhance the problem solving and independent student learning. Teachers should have the ability to increase the independence of student learning. Thus it can be said that the open-ended approach can be used as an alternative to learning that is used by teachers in training and developing mathematical problem-solving abilities and students' self-defense.

In contemporary mathematics learning, it is known that there are several learning approaches that have been proven to be able to improve problem-solving abilities better than conventional approaches, including the Openended approach, according to Roy Killen (Sanjaya, Wina; 2009) two approaches to learning, including the approach that teacher-centered which derives direct learning strategies and student-centered approaches, namely students derive discovery learning strategies. One example of this approach is the open-ended approach. This learning approach will be used in research to minimize the above problems. This learning approach was chosen because it is in line with government programs in an effort to improve the quality of mathematics education. In addition, this is also based on the views of experts regarding the approach.

Open-ended approach, Nohda (2000) argues that an open-ended approach is very important for every student to have the freedom to improve their problem-solving abilities according to their level of ability and interest. According to Yamzaki (Hino, 2007), teaching mathematics using open questions is one of the representative methods for solving student problems. Based on the results of Radley's research (2007) from several research findings he did in 2007 on 11 th grade mathematics students in two schools, one experimental and one other control. In his study, the authors claim that an open approach to teaching and learning mathematics improves students' understanding of mathematics.

According to Suherman, et al (2003) the open-ended approach has several advantages, including: (a) students participate more actively in learning by expressing their ideas, (b) have comprehensive mathematical knowledge and skills, (c) low mathematical abilities can respond to problems in their own way, (d) intrinsically motivated to provide evidence or explanation. (e) Have a lot of experience to find something to answer the problem.

Open-ended learning is a learning approach by providing open problems to students. According to Suherman, et al. (2003) that student activities must be open, namely learning activities must accommodate students' opportunities to do everything freely according to their wishes. Learning activities must lead students to answer problems in many ways and possibly many (correct) answers. Open-ended problems are problems that are formulated to have many methods of solving and more than one correct answer (Shimada, 1997). So that it invites the intellectual potential and experiences of students in the process of finding something new.

Learning with an open-ended approach not only provides open problem problems to students but when students carry out mathematical activities to solve the given problems, it will automatically encourage their potential to carry out mathematical activities at a higher level of thinking. Thus, the teacher does not need to direct students to solve problems in a specified way or pattern, because it will hinder students' freedom of thought to find new ways of solving problems.

Referring to the above opinion, it can be concluded that the open-ended learning approach provides students with opportunities to improve their learning abilities and independence in mathematics lessons, because in this lesson a concept of "many roads to home" is presented, which means that there are many solutions and correct answers. which raises curiosity about how other students complete the problem to find a final solution (Setiawan and Harta. 2014; Tanjung, D.F et al. 2020) so that learning will be more fun besides this approach causes them to discuss more, exchange ideas and even to argue within his group members. This is where students are involved in mathematical processes such as specialization, exploration, conjecturing, diversification, and generalization which will increase mathematical problem solving and students' learning independence towards mathematics.

\section{METHODOLOGY}

The method used was Quasi-Experimental Design is the design that has control but can not serve to control the variables that affect the performance of an experiment (Sugiyono, 2014). The design of this research is The Nonequivalent Posttest-Only Control Group Design. The study population was all students of class VII MTs Negeri 1 Bandar Rice semester in the academic year 2018/2019 consisting of 6 classes with the number of 207 students. Purposive sampling is a sampling technique with certain considerations (Sugiyono, 2014).

Sampling using purposive sampling in accordance with the purpose of the study saw differences in problem solving abilities using different learning approaches. Sampling is based on consideration of the homogeneity of students which is also supported by the statement of the teacher who teaches the class who says that the two groups of students sampled have the same problem-solving abilities, so that they can be used as research samples. The sample in this research is class VII-1, amounting to 32 as an experimental class and class VII-2 amounted to 32 people as a control group. In the experimental class and control class is given questionnaires before treatment for student 
IJEMS: Indonesian Journal of Education and Mathematical Science

2021 Vol. 1, No. 1, pp. 11-18

$\operatorname{ISSN}(e): 2715-985 x$

DOI: https://doi.org/10.30596/ijems.v1i3.2602

(C)2020IJEMS@UMSU.All Rights Reserved.

learning independence. There are three levels of the student learning independence scale, namely, high, medium and low. The study design can be seen in Table 1 below.

Table 1. Open Ended Approach to Problem Solving Ability and Student Learning Independence

\begin{tabular}{|l|c|c|c|}
\hline \multicolumn{1}{|c|}{$\begin{array}{c}\text { Independent } \\
\text { learning }\end{array}$} & $\begin{array}{c}\text { High } \\
(\mathrm{T})\end{array}$ & $\begin{array}{c}\text { Medium } \\
(\mathrm{S})\end{array}$ & $\begin{array}{c}\text { Low } \\
(\mathrm{R})\end{array}$ \\
\hline Experiment (A) & TA & SA & RA \\
\hline Control (B) & TB & SB & RB \\
\hline
\end{tabular}

The data collection techniques used in this study was tests and non-tests. The tests used by researchers were tests of mathematical problem solving abilities and non-tests used by researchers were questionnaires, observation, and documentation. The tool used to measure students' mathematics learning independence is a questionnaire, where the questionnaire is calculated using a Likert scale, this scale assesses the attitudes or behavior desired by researchers by asking several questions with four choices to be given, namely strongly agree, agree, disagree. Agree, strongly disagree with the respondent.

The hypothesis in this study can be formulated into an alternative hypothesis (Ha) and the null hypothesis (Ho) as follows:

1. $\mathrm{H}_{\mathrm{a}}=$ There is an influence on students' mathematical problem solving ability between students who learn using the Open-Ended approach and students who learn without using the Open-Ended approach.

$\mathrm{H}_{\mathrm{o}}=$ There is no influence on students' mathematical problem solving abilities between students who learn using the Open-Ended approach and students who learn without using the Open-Ended approach

2. $\mathrm{H}_{\mathrm{a}}=$ There is an influence on students' mathematical problem solving ability among students who have high, medium, and low learning independence.

$\mathrm{H}_{0}=$ There is no influence on students' mathematical problem solving abilities among students who have high, medium, and low learning independence.

3. $\mathrm{H}_{\mathrm{a}}=$ There is an influence of the interaction between the learning model and students 'learning independence on students' mathematical problem solving abilities.

$\mathrm{H}_{0}=$ There is no influence of the interaction between the learning model and the independent learning of students on students' mathematical problem solving abilities.

\section{RESULT AND DISCUSSION}

The technique used in analyzing the data to test hypothesis 1 using t-test, hypothesis 2 and 3 using two-way ANOVA. This test aims to investigate whether there is any difference between the mathematical problem solving ability of students with learning approach Open Ended and students who have not applied learning approach Open Ended based independent learning group students of high, medium and low. The first step the researcher took: giving questions of the initial mathematical ability between the experimental class and control class students was the same or not. The test results were then analyzed using the two-way ANOVA test, and the data was calculated using the SPSS for 20 applications.

Data on the students' initial mathematics ability in the experimental class and control class can be seen in table 2 below.

Table 2. Data of Initial Mathematics Ability (KAM)

\begin{tabular}{|c|c|c|c|c|c|c|}
\hline CLASS & Ideal Value & $\mathbf{N}$ & $\mathbf{X}_{\text {Min }}$ & $\mathbf{X}_{\text {Max }}$ & mean & $\begin{array}{c}\text { Standard } \\
\text { Deviation }\end{array}$ \\
\cline { 1 - 5 } Experiment & \multirow{2}{*}{100} & 32 & 33,3 & 80 & 51,66 & 13,65 \\
\cline { 1 - 5 } Control & & 32 & 33,3 & 66,67 & 47,27 & 11,40 \\
\hline
\end{tabular}

Table 2 above shows that the value of the lowest KAM the experimental class and control class with a value of 33.3, the highest score in the experimental class is 80 and the control group was 66.67. While the mean value of KAM in the experimental class was 51.66 and in the control class it was 47.27 and the standard deviation in the experimental class was 11.65 and in the control class it was 11.40. This shows that the average KAM score for each class of the study sample is not much different. Before using the t-test, the normality and homogeneity of the test 
IJEMS: Indonesian Journal of Education and Mathematical Science

2021 Vol. 1, No. 1, pp. 11-18

$\operatorname{ISSN}(e): 2715-985 x$

DOI: https://doi.org/10.30596/ijems.v1i3.2602

(C)2020IJEMS@UMSU.All Rights Reserved.

data for the mathematical problem-solving abilities of the two groups must first be tested. The results of the normality test for the Students' Initial Mathematics ability are presented in table 2 below.

Table 3. Normality Test of Students' Initial Mathematics Ability (KAM)

\begin{tabular}{|c|c|c|c|c|c|c|}
\hline \multirow{2}{*}{ class } & \multicolumn{2}{|c|}{ Kolmogorov-Smirnov $^{\mathrm{a}}$} & \multicolumn{3}{c|}{ Shapiro-Wilk } \\
\cline { 2 - 7 } & Statistic & $\mathrm{df}$ & Sig. & Statistic & $\mathrm{df}$ & Sig. \\
\hline Experiment &, 147 & 32 &, 075 &, 932 & 32 &, 045 \\
\hline Control &, 144 & 32 &, 088 &, 883 & 32 &, 002 \\
\hline
\end{tabular}

a. Lilliefors Significance Correction

Based on Table 3 above, significant values are respectively 0.075 and 0.088 for the experimental class and control class. The second value is significant at each learning class is greater than the significance level of 0.05 , Ho is accepted and others rejected. So Ho stating samples come from populations with normal distribution for the experimental class and control class is acceptable. The next step is to test the homogeneity of the students' initial mathematics ability data which is presented in table 4 below.

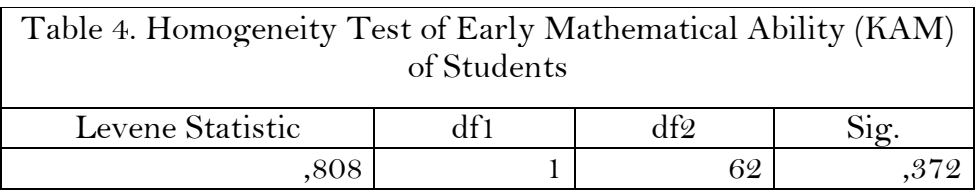

Based on Table 4 above, the significant value of 0.372 is greater than the significant level of 0.05. So that $\mathrm{H}_{0}$ which states the variance in each group is the same can be accepted. This shows that the two classes have homogeneous data variance. Furthermore, the $t$ test is carried out. The results of the $t$ test for the preliminary questions are presented in table 5 below.

Table 5. "t” Test of Students' Initial Mathematics Ability (KAM)

\begin{tabular}{|l|c|c|c|c|r|}
\hline & \multicolumn{5}{|c|}{ t-test for Equality of Means } \\
\cline { 2 - 6 } & $\mathrm{t}$ & $\mathrm{Df}$ & $\begin{array}{c}\text { Sig. } \\
\text { (2-tailed) }\end{array}$ & $\begin{array}{c}\text { Mean } \\
\text { Difference }\end{array}$ & $\begin{array}{c}\text { Std. Error } \\
\text { Difference }\end{array}$ \\
\hline Equal variances assumed & 1,396 & 62 &, 168 & 4,39156 & 3,14507 \\
\hline $\begin{array}{l}\text { Equal variances not } \\
\text { assumed }\end{array}$ & 1,396 & 60,100 &, 168 & 4,39156 & 3,14507 \\
\hline
\end{tabular}

Based on the results of the calculations in table 5 above using the $t$ test, it is obtained that $t$ count is 1.396 with a sig value of 0.168 while $t$ table is 1.99 . Because $t_{\text {count }}<t_{\text {table }}(1.396<1.99)$ and $\operatorname{sig}>\alpha(0.168>0.05)$, so $\mathrm{H}_{0}$ is accepted. So it can be concluded that there is no difference in the average Initial Mathematics Ability (KAM) between the experimental class and the control class. Thus, the experimental class and the control class have the same abilities.

The next step. After knowing that there is no difference in the initial mathematical abilities of the experimental and control class students, is to group students based on students' learning independence through the provision of independence questionnaires. After giving the questionnaire to the experimental class and the control class, the results of the questionnaire were analyzed to be grouped with high, medium and low criteria. The criteria for determining student learning independence (Azwar, 2012) are as in table 6 below.

Table 6. Categories of Students' Learning Independency Level

\begin{tabular}{|c|c|}
\hline Criteria & Category \\
\hline $\mathrm{X}>(\mu+\mathrm{SD})$ & High \\
\hline$(\mu-\mathrm{SD}) \leq \mathrm{X} \leq(\mu+\mathrm{SD})$ & medium \\
\hline $\mathrm{X}<(\mu-\mathrm{SD})$ & Low \\
\hline
\end{tabular}

While the summary results are presented in table 7 below.

Table 7.Categories of Learning Independence Score Grouping

\begin{tabular}{|c|c|c|c|}
\hline \multirow{2}{*}{ class } & \multicolumn{3}{|c|}{ Student Abilities } \\
\cline { 2 - 4 } & low & medium & high \\
\hline Experiment & 5 & 20 & 7 \\
\hline Control & 8 & 19 & 5 \\
\hline total & 13 & 39 & 12 \\
\hline
\end{tabular}

Based on Table 7 above, it is found that in the experimental class which will then be taught through open learning there are 5 low-ability students, 20 medium-capable students, and 7 high-ability students, while in the 
IJEMS: Indonesian Journal of Education and Mathematical Science

2021 Vol. 1, No. 1, pp. 11-18

$\operatorname{ISSN}(e): 2715-985 x$

DOI: https://doi.org/10.30596/ijems.v1i3.2602

(C)2020IJEMS@UMSU.All Rights Reserved.

control class that will be taught through conventional learning there are 8 low-ability students, 19 medium ability students, and 5 high ability students. After the entire meeting was completed, the two classes were given a posttest to measure the students' mathematical problem abilities. After presenting the posttest questions, the results were analyzed to find out whether anyone handled the students' mathematical problems between the two classes. Before the two-way ANOVA test was carried out, the first steps to be achieved were the normality and homogeneity tests. The results of the normality test of students' mathematical problem abilities can be seen in table 8 below.

Table 8 the normality test of the Posttest questions

\begin{tabular}{|l|r|r|r|r|r|r|}
\hline \multirow{2}{*}{ class } & \multicolumn{3}{|c|}{ Kolmogorov-Smirnov $^{\mathrm{a}}$} & \multicolumn{3}{c|}{ Shapiro-Wilk } \\
\cline { 2 - 7 } & Statistic & \multicolumn{1}{c|}{$\mathrm{df}$} & \multicolumn{1}{c|}{ Sig. } & Statistic & \multicolumn{1}{c|}{ Df } & \multicolumn{1}{c|}{ Sig. } \\
\hline Experiment &, 093 & 32 &, $200^{*}$ &, 969 & 32 &, 476 \\
\hline Control &, 124 & 32 &, $200^{*}$ &, 926 & 32 &, 030 \\
\hline
\end{tabular}

*. This is a lower bound of the true significance.

a. Lilliefors Significance Correction

In table 8 , the posttest experimental class and control class are normally distributed. Furthermore, it will be tested whether the posttest variance of the experimental class and the control class is the same. The test instrument used to test the homogeneity of the posttest items was the Levene test. The results of the posttest homogeneity test are presented in table 9 below.

Table 9. Homogeneity Test of Posttest Questions

\begin{tabular}{|c|c|c|c|}
\hline Levene Statistic & df1 & $\mathrm{df} 2$ & Sig. \\
\hline ,957 & 1 & 62 & ,332 \\
\hline
\end{tabular}

From Table 9 that the sig of the posttest results is 0.332. The Sig value is greater than the significance level $\alpha=0.05$, so the null hypothesis which states that there is no difference in the variance of the posttest score between the experimental class and the control class is accepted. below.

Furthermore, hypothesis testing is carried out using the two-way ANOVA which is presented in table 10

Table 10. Two-way Anova Test Results

Dependent Variable: Mathematical Problem Solving Ability

\begin{tabular}{|l|r|r|r|r|r|}
\hline Source & $\begin{array}{c}\text { Type III Sum of } \\
\text { Squares }\end{array}$ & \multicolumn{1}{c|}{$\mathrm{df}$} & Mean Square & F & Sig. \\
\hline Corrected Model & $1681,996^{\mathrm{a}}$ & 5 & 336,399 & 5,224 &, 001 \\
\hline Intercept & 166943,499 & 1 & 166943,499 & 2592,318 &, 000 \\
\hline Learning_approaches & 499,279 & 1 & 499,279 & 7,753 &, 007 \\
\hline Independent_Learning & 647,730 & 2 & 323,865 & 5,029 &, 010 \\
\hline $\begin{array}{l}\text { Learning_Approach * } \\
\text { Learning_Independence }\end{array}$ & 31,582 & 2 & 15,791 &, 245 &, 783 \\
\hline Error & 3735,160 & 58 & 64,399 & & \\
\hline Total & 238747,213 & 64 & & & \\
\hline Corrected Total & 5417,156 & 63 & & & \\
\hline
\end{tabular}

a. R Squared $=, 310$ (Adjusted R Squared $=, 251$ )

The basis for making decisions on the two-way ANOVA test is:

1. If the significance value (Sig.) $<0.05$, then there is an effect of the students' mathematical problem solving ability based on the factor variables;

2. If the significance value (Sig.) $>0.05$, then there is no effect of students' mathematical problem solving abilities based on factor variables.

Based on table 10 shows the learning approach with a significance value of the learning approach 0.007 , then $0.007<0.05 \mathrm{H}_{0}$ is rejected. So it can be concluded that there is an influence on students' mathematical problem solving abilities between students who learn using the Open-Ended approach and students who learn without using the OpenEnded approach. The significance value of learning independence is 0.01 , then $0.01<0.05, \mathrm{H}_{0}$ is rejected. So it is concluded that there is an influence on the ability of mathematical problem solving among students who have high, medium, and low learning independence. This is in accordance with the research of Hendrayana and Thaib (2014) which explains that the learning independence of students is on average included in the high category. Furthermore, 
IJEMS: Indonesian Journal of Education and Mathematical Science

2021 Vol. 1, No. 1, pp. 11-18

$\operatorname{ISSN}(e): 2715-985 x$

DOI: https://doi.org/10.30596/ijems.v1i3.2602

(C)2020IJEMS@UMSU.All Rights Reserved.

the significance value of the learning approach and learning independence is 0.783 , then $0.783<0.05$, $\mathrm{H}_{\mathrm{o}}$ is accepted. So it is concluded that there is no influence of the interaction between the learning model and the students 'learning independence on students' mathematical problem solving abilities.

\section{CONCLUSION}

From the results of the research that has been carried out, the following conclusions are obtained:

1. Open-ended learning has a more significant effect than learning without open-ended learning on students' mathematical problem solving abilities.

2. Open-ended learning has a more significant effect than learning without open-ended learning on student learning independence.

3. There is no interaction between open-ended learning and independent learning on students' mathematical problem solving abilities.

\section{REFERENCES}

Aini, I. N. (2016). Upaya Meningkatkan Kemampuan Pemecahan Masalah Matematik Siswa Melalui Pendekatan Open-Ended. JES-MAT (Jurnal Edukasi dan Sains Mat., vol. 2, no. 2, pp. 29-40.

Azwar, Saifuddin. (2012). Penyusunan Skala Psikologi. Jogyakarta : Pustaka Pelajar.

Dahlan, J. A. (2016). Pendekatan Open-Ended dalam Pembelajaran Matematika,” J. Pendidik. Mat., vol. 4, no. 1, pp. $1-15,2016$

Haris Mujiman. (2011). Manajemen Pelatihan Berbasis Belajar Mandiri. Yogyakarta: Pustaka Pelajar.

Haryati, F. and Sari, A. W. (2018). Pengaruh Pembelajaran Dengan Pendekatan Open Ended Terhadap Kemampuan Pemecahan Masalah Matematis Mahasiswa Pada Mata Kuliah Kalkulus FKIP UMSU. Intiqad J. Agama dan Pendidik. Islam, vol. 10, no. 1, pp. 35-49,

Hendrayana, A. S. dan Thaib, D. (2014). Motivasi Belajar, Kemandirian Belajar dan Prestasi Belajar Mahasiswa Beasiswa Bidikmisi di UPBJJ UT Bandung, J. Pendidik. Terbuka dan Jarak Jauh, vol. 15, no. 2, pp. 81-87.

Hino, K. (2007).Toward the Problem-Centered Classroom: Trends in Mathematical Problem Solving in Japan. Journal ZDM Mathematics Education V.39: PP. 503-514.

Irvan, Mushlihuddin, R and Suhartini. (2020). Effectiveness Of Learning Media Using Contextual Based Macromedia Flash for Junior School Students Al Hikmah Medan. IOP Conf. Series: Journal of Physics: Conference Series 1429 (1), 012002

Nohda, N., (2000). Learning and Teaching Through Open-ended Approacrh Method. Dalam Tadao Nakahara dan Masataka Koyama (editor) Proceeding of the $24^{\text {th }}$ of the Intenational Group for the Psychology of Mathematics Education. Hiroshima : Hiroshima University.

Permendikbud. (2016). Permendikbud No 21 Tahun 2016

Sanjaya, Wina. 2009. Strategi Pembelajaran Berorientasi Standar Proses Pendidikan. Prenada: Jakarta.

Setiawan, Raden Heri. dan Harta. Idris (2014). Pengaruh Pendekatan Open-Ended dan Pendekatan Kontekstual terhadap Kemampuan Pemecahan Masalah dan Sikap Siswa terhadap Matematika. Jurnal Riset Pendidikan Matematika Vol. 1, no. 2, pp. 241-257

Shimada, S. (1997). The Significance of an Open-Ended Approach. In Shimada, S. dan Becker, J.P. (Ed). The OpenEnded Approach. A New Proposal for Teaching Mathematics. Reston: VA NCTM.

Sugiyono. (2014) Metodelogi Penelitian Kuantitatif, Kualitatif Dan R \& D. Bandung: ALFABETA

Suherman, Erman dkk. (2003). Strategi Pembelajaran Matematika Kontemporer. Bandung: PT Remaja Rosdakarya.

Sumartini, T. S. (2018). Peningkatan Kemampuan Pemecahan Masalah Matematis Siswa melalui Pembelajaran Berbasis Masalah,” Mosharafa J. Pendidik. Mat., vol. 5, no. 2, pp. 148-158.

Tanjung D. F; Syahputra, E. and Irvan. (2020). Problem Based Learning, Discovery Learning, and Open Ended Models: An experiment On Mathematical Problem Solving Ability, JTAM |J. Teor. dan Apl. Mat., vol. 4, no. 1, p. 9.

Yamin, Martinis. 2008. Desain Pembelajaran Berbasis Tingkat Satuan Pendidikan. Jakarta: Gaung Persada Press. 